\title{
Occurrence of quinolone-resistant Escherichia coli in environmental samples from a sow pool system in Switzerland
}

\author{
von Ah, Sereina ; Stephan, Roger ; Zurfluh, Katrin ; Sidler, X ; Kümmerlen, Dolf
}

\begin{abstract}
Fluoroquinolones (FQ) undergo minimal metabolization in animals and are excreted via faeces and urine, where they enter the environment almost unchanged. In this study we investigated the presence of quinolone-resistant Escherichia coli (E. coli) in the environment of 65 farms of a sow pool system in Switzerland. Two hundred and seventy-nine samples from liquid manure and wipes of dust and pen walls were collected and the use of FQ on the farms was investigated. From $45 \%$ of dust samples, $52 \%$ of pen wall samples and $69 \%$ of liquid manure samples quinolone-resistant E. coli (QRE) were cultivated. Significant higher counts of quinolone-resistant colonies were found in liquid manure samples than in dust $(p<0.01)$ or pen wall samples ( $p$ $<0.05$ ). Samples from breeding farms were significantly more often positive than samples from fattening farms $(\mathrm{p}<0.01)$. Samples taken from farms using FQ were significantly more frequently positive for QRE than samples from farms without FQ usage ( $p<0.01)$. On $97 \%$ of the farms with FQ use and 85\% $(23 / 27)$ of the farms without FQ use QRE could be found in at least one sample (no significant difference). Overall, QRE were widespread in the environment of the investigated pig farms.
\end{abstract}

DOI: https://doi.org/10.17236/sat00211

Other titles: Vorkommen von Chinolon -resistenten Escherichia coli in Umweltproben aus einem arbeitsteiligen Ferkelproduktionsring

Posted at the Zurich Open Repository and Archive, University of Zurich

ZORA URL: https://doi.org/10.5167/uzh-171122

Journal Article

Published Version

Originally published at:

von Ah, Sereina; Stephan, Roger; Zurfluh, Katrin; Sidler, X; Kümmerlen, Dolf (2019). Occurrence of quinoloneresistant Escherichia coli in environmental samples from a sow pool system in Switzerland. Schweizer Archiv für Tierheilkunde, 161(6):387-394.

DOI: https://doi.org/10.17236/sat00211 


\title{
Occurrence of quinolone-resistant Escherichia coli in environmental samples from a sow pool system in Switzerland
}

\author{
S. von Ah¹, R. Stephan², K. Zurfluh², X. Sidler', D. Kümmerlen¹ \\ 1 Division of Swine Medicine, Department of Farm animals, Vetsuisse Faculty, University of Zurich, \\ Winterthurerstrasse 260, 8057 Zurich, Switzerland; ${ }^{2}$ Institute for Food Safety and Hygiene, Vetsuisse Faculty, \\ University of Zurich, Winterthurerstrasse 272, 8057 Zurich, Switzerland
}

\begin{abstract}
Summary
Fluoroquinolones (FQ) undergo minimal metabolization in animals and are excreted via faeces and urine, where they enter the environment almost unchanged. In this study we investigated the presence of quinolone-resistant Escherichia coli (E. coli) in the environment of 65 farms of a sow pool system in Switzerland. Two hundred and seventy-nine samples from liquid manure and wipes of dust and pen walls were collected and the use of FQ on the farms was investigated. From $45 \%$ of dust samples, $52 \%$ of pen wall samples and $69 \%$ of liquid manure samples quinolone-resistant $E$. coli (QRE) were cultivated. Significant higher counts of quinolone-resistant colonies were found in liquid manure samples than in dust $(\mathrm{p}<0.01)$ or pen wall samples $(\mathrm{p}<0.05)$. Samples from breeding farms were significantly more often positive than samples from fattening farms $(p<0.01)$. Samples taken from farms using FQ were significantly more frequently positive for $\mathrm{QRE}$ than samples from farms without FQ usage $(\mathrm{p}<0.01)$. On $97 \%$ of the farms with FQ use and $85 \%(23 / 27)$ of the farms without FQ use QRE could be found in at least one sample (no significant difference). Overall, QRE were widespread in the environment of the investigated pig farms.
\end{abstract}

Keywords: Quinolone resistance, fluoroquinolones, liquid manure samples, resistance profile, pigs, dust samples

\section{Vorkommen von Chinolon -resisten- ten Escherichia coli in Umweltproben aus einem arbeitsteiligen Ferkel- produktionsring}

Fluorchinolone (FQ) werden bei Tieren nur minimal metabolisiert und nahezu unverändert über Kot und Urin ausgeschieden. In der vorliegenden Studie wurden Umweltproben aus 65 Betrieben eines arbeitsteiligen Ferkelproduktionsrings in der Schweiz auf das Vorkommen von FQ-resistenten Escherichia coli (E. coli) untersucht. In den Betrieben wurden 279 Proben von Gülle und Staub, sowie Wischproben von den Buchtenwänden gesammelt und der Einsatz von FQ wurde untersucht. Chinolon-resistente E. coli (QRE) wurden aus 45\% der Staubfilterproben, 52\% der Stallwandproben und 69\% der Gülleproben kultiviert. Die Gülleproben enthielten signifikant höhere QRE-Koloniezahlen als Staub$(\mathrm{p}<0.01)$ und Wischproben $(\mathrm{p}<0.05)$. Proben aus Zuchtbetrieben waren signifikant häufiger positiv, als Proben aus Mastbetrieben $(\mathrm{p}<0.01)$. Proben aus Betriebe mit FQ-Einsatz waren signifikant häufiger positiv für QRE als Betriebe ohne FQ-Einsatz. In 97\% der Betriebe mit FQ-Einsatz und 85\% (23/27) der Betriebe ohne FQ-Einsatz konnte QRE in mindestens einer Probe nachgewiesen werden (kein signifikanter Unterschied). Insgesamt waren QRE in der Umgebung der untersuchten Schweinezuchtbetriebe weit verbreitet.

Schlüsselwörter: Chinolonresistenz, Fluorchinolone, Gülleproben, Resistenzprofil, Schweine, Staubproben https://doi.org/ $10.17236 /$ sat00211

Received: 13.04.2018 Accepted: 08.04.2019 
Occurrence of quinoloneresistant Escherichia coli in environmental samples from a sow pool system in Switzerland

S. von Ah et al.

\section{Introduction}

Antimicrobial resistance is considered by the World Health Organization (WHO) to be one of the biggest challenges facing both animal and human health. ${ }^{31}$ Worldwide efforts are undertaken to investigate antimicrobial resistance and the spread of resistant bacteria. In Switzerland, the Federal Department of Home Affairs (EDI) and the Federal Department of Economic Affairs, Education and Research (WBF) have adopted the "Strategy on Antibiotic Resistance (StAR)". This project promotes intensified investigations of the impact of antimicrobial usage on the environment and its role in the spread of antimicrobial-resistant bacteria. ${ }^{11}$

The assocation of the use of antimicrobials and the selection of resistant bacteria can be caused by direct as well as cross selection..$^{18}$ Moreover, associations between antimicrobial treatments of sows and antimicrobial resistance in their offspring could be found. ${ }^{8}$ Beside antimicrobial use, parameters in health management such as space allowance, stable temperature or production size have been identified as risk factors for the development of antimicrobial resistanc. ${ }^{6}$ A prudent use of antimicrobials and antimicrobial stewardship ensure that as few animals as possible are subjected to antimicrobial therapy, and in turn, as few microorganisms as possible are exposed to minimal selective concentrations of antimicrobials or concentrations below mutant prevention levels. ${ }^{12}$

The routes drug residues and resistant bacteria take into the environment after antimicrobial therapy of an animal are complex. Regardless of the type of application, the microbial flora of the treated animals is always subjected to a selection pressure. This creates a pool of bacteria which can serve as a reservoir for the transmission of resistance mechanism. ${ }^{17,21} \mathrm{~A}$ shift in susceptibility of commensal E. coli towards resistance could be shown in pigs intramusculary treated with fluoroquionolones and in untreated penmates. ${ }^{26}$ In the case of oral therapy with pharmaceutical premixes, surrounding bacterial flora come into direct contact with residues of active substances in dust and feed in the barn. ${ }^{14}$ Certain active substances, such as tetracyclines or fluoroquinolones, undergo limited metabolization in pigs and are thus effectively excreted. ${ }^{28,30}$ Environmental bacteria consequently come into contact with antimicrobial residues through excretions of treated animals and through direct contamination during oral treatments. Significant concentrations of tetracycline could be found in liquid manure and an accumulation of active substances in soil fertilized with liquid manure could be demonstrated. ${ }^{15}$ The examination of indicator bacteria for antimicrobial resistance such as $E$. coli provides an insight into the presence of resistance in the enormous bacterial reservoir in the environment of farm animals. The longeiv- ity of antimicrobial residues or resistant bacteria in different materials and the spread into the environment of pig farms has been investigated before. Dust samples collected over 20 years in pig stock and stored at $4{ }^{\circ} \mathrm{C}$ contained considerable antimicrobial residues. ${ }^{14}$ Air samples near a pig farm showed 287 times more resistant bacteria when taken downwind the barn than if taken upwind. With increasing distance downwind, the number of resistant bacteria decreased exponentially but was still 2.2 times higher after $150 \mathrm{~m}$ than upwind. ${ }^{13}$ The main molecular resistance mechanisms for the development of quinolone/fluoroquinolone resistance are mutations in the chromosomally coded gyrA and parC genes. Single mutations first lead to quinolone resistance and further multiple mutations can additionally cause FQ resistance. ${ }^{24}$ In order to assess the possible influence of the use of fluoroquinolones in farms on the gradual selection of quinolone/fluoroquinolone-resistant E. coli, in the present study QRE were isolated from environmental samples (dust, liquid manure and wipe samples of pen walls). The following questions were addressed: - Is the occurence and microbial count of QRE different in the different environmental samples?

- Does the occurence of QRE differ between farms with and without use of fluoroquinolone?

\section{Material and methods}

All 65 pig farms of a sow pool system and related fattening farms were visited between May and November 2016. In a sow pool system, sows are transported between farms housing them either during the mating, gestation (mating/gestation farms) or farrowing (farrowing farms) period. The sow pool consisted of 26 farrowing farms, 29 fattening farms and 10 mating and gestation farms All fattening farms included in this study were supplied with piglets by this sow pool. The farms were located at the Swiss Midlands within a radius of approximately 80 $\mathrm{km}$. Veterinary service was provided individually for each farm by in total 33 veterinary practices. In order to include all relevant treatments with FQ that could cause significant residues in the environment, Data concerning antimicrobial use during 18 months prior sampling was taken from treatment journals on farm and drug prescriptions of the veterinarians in 2015 and 2016. It was also recorded whether cleaning and disinfection was regularly carried out in the stables. During the farm visits, wipe samples from dust and pen walls were taken and the slurry pits were also sampled. Collecting the samples was carried out representing the number of buildings and the number of slurry pits of the farms. In order to reflect the compartmentation of the study farms, each building or completely separated room on the farms was tested seperately. On farms with separated slurry pits, a corresponding number of slurry samples was taken. Dust 
was collected from horizontal surfaces such as the lids of piglet nests, window sills or feed or water pipelines by wiping using a cotton stocking moistened with sterile $0.85 \%$ saline solution. For each sample of pen walls, the walls were rubbed at animal level in two or three randomly selected pens, again using moistened cotton stockings. For each of the dust and pen wall samples a total area of about $0.12 \mathrm{~m}^{2}$ was sampled. Depending on accessibility, liquid manure samples were taken from the slurry pit, or if this was not possible, from the slurry channel. For this purpose, at least three samples of one litre each were taken from different depths or at different points, mixed in a bucket and a sample of 300-500 $\mathrm{ml}$ was taken. The samples were then stored at $-20^{\circ} \mathrm{C}$.

\section{Laboratory methods}

Environmental samples were tested for the presence of $E$. coli with phenotypic quinolone resistance. For the qualitative detection of QRE, an average of $1.91 \mathrm{~g} \mathrm{sam}$ ple was diluted 1:10 in Enterobacteriaceae Enrichment Broth (EE-Broth) and incubated at $37^{\circ} \mathrm{C}$ overnight. The enrichment was then spread on Rapid-E. coli 2 agar (Biorad, Munich), supplemented with $8 \mu \mathrm{g} / \mathrm{ml}$ nalidixic acid and $5 \mu \mathrm{g} / \mathrm{ml}$ amphotericin $\mathrm{B}$, and cultivated overnight at $37^{\circ} \mathrm{C}$. On the following day, it was documented whether QRE ( $\beta$-D-glucuronidase and $\beta$-D-galactosidase positive) had grown. For a semi-quantitative approach, the samples, averaging $1.97 \mathrm{~g}$, were diluted in a ratio of $1: 10$ in $0.85 \%$ saline solution and homogenized in a stomacher. The homogenate was spatulated in two dilution steps $(1: 100,1: 1000)$ on Rapid-E. coli 2 agar plates supplemented with $8 \mathrm{\mu g} / \mathrm{ml}$ nalidixic acid and $5 \mu \mathrm{g} / \mathrm{ml}$ amphotericin B. After incubation at $37^{\circ} \mathrm{C}$ overnight, the presumptive colonies were counted.
E. coli isolates randomly selected from each positive sample were then tested for susceptibility to 15 different antimicrobials using the agar diffusion method. ${ }^{9}$ The following antimicrobials were tested: Amoxicillin-clavulanic acid (AMC30), ampicillin (AM10), azithromycin (AZM15), cefazolin (CZ30), cefepime (FEP30), cefotaxime (CTX30), chloramphenicol (C30), ciprofloxacin (CIP5), fosfomycin (FOS200), gentamicin (GM10), kanamycin (K30), nitrofurantoin (F/M300), streptomycin (S10), sulfamethoxazole-trimethoprim (SXT) and tetracycline (TE10) (Becton Dickinson, Heidelberg, Germany).

\section{Data analysis and statistical evaluation}

Data were evaluated and graphically displayed in Microsoft Excel 2011 (Microsoft, Redmond, WA, USA) and R-Studio Version 0.99.902 (Free Software Foundation, Boston, MA, USA). The prevalence of QRE in different sample types was compared by the Pearson's Chi-squared test. The number of QRE in different sample types was compared with the Kruskal-Wallis rank sum test and the Wilcoxon rank sum test.

\section{Results}

\section{Antimicrobial use prior sampling}

Data on antimicrobial usage was missing or not complete in nine of 65 participating farms. Twenty-nine of the study farms had been using FQ during 18 months prior to sampling and 27 farms had not. Seventy-three percent of the farrowing farms in this study had been using FQ, $50 \%$ of the mating/gestation farms and $10 \%$ of the fattening farms. According to prescriptions of the
Occurrence of quinoloneresistant Escherichia coli in environmental samples from a sow pool system in Switzerland

S. von Ah et al.

Table 1: Number of mating/gestation farms, farrowing farms and fattening farms using fluoroquinolones (FQ +), not using fluoroquinolones (FO -) or without data (nd) and number of farms with one, two, three or four samples of dust and pen walls.

\begin{tabular}{|c|c|c|c|c|c|c|}
\hline & No of farms & One sample & Two samples & Three samples & Four samples & Total of samples \\
\hline Gestation farms & 10 & 9 & & 1 & & 12 \\
\hline $\mathrm{FO}+$ & 5 & 5 & & & & 5 \\
\hline FO - & 4 & 3 & & 1 & & 6 \\
\hline nd & 1 & 1 & & & & 1 \\
\hline Fattening farms & 29 & 21 & 8 & & & 37 \\
\hline $\mathrm{FO}+$ & 3 & & 3 & & & 6 \\
\hline $\mathrm{FQ}-$ & 21 & 16 & 5 & & & 26 \\
\hline nd & 5 & 5 & & & & 5 \\
\hline Farrowing farms & 26 & 10 & 8 & 3 & 5 & 55 \\
\hline $\mathrm{FQ}+$ & 19 & 8 & 4 & 2 & 5 & 42 \\
\hline $\mathrm{FQ}-$ & 4 & & 4 & & & 8 \\
\hline nd & 3 & 2 & & 1 & & 5 \\
\hline Total & 65 & 40 & 16 & 4 & 5 & 104 \\
\hline $\mathrm{FQ}+$ & 27 & 13 & 7 & 2 & 5 & 53 \\
\hline FO - & 29 & 19 & 9 & 1 & 0 & 40 \\
\hline nd & 9 & 8 & 0 & 1 & 0 & 11 \\
\hline
\end{tabular}


Occurrence of quinoloneresistant Escherichia coli in environmental samples from a sow pool system in Switzerland

S. von Ah et al. veterinarians and treatment journals, FQ (enrofloxacin and marbofloxacin) were used for the treatment of the Postpartum Dysgalactia Sydrome (PDS) or fever in sows and for diarrhea of piglets. In fattening pigs FQ were used to treat fever and pneumonia. Treatments with FQ of sows, fattening pigs and piglets were carried out in a dosage

$2-2.5 \mathrm{mg} / \mathrm{kg}$ bodyweight intramuscularly for three days. In case of oral treatments of piglets, the dosage was $1.7 \mathrm{mg} / \mathrm{kg}$ for three days. In individual cases, farmers deviated from the recommended treatment duration and treated only once.

Twenty nine percent of the farms had been using tetrayclines during the investigated period. Sulfonamide-trimethoprim combinations had been used in $29 \%$, penicillins in $50 \%$ and streptomycin in $41 \%$ of the farms. Fifty-eight farms reported to clean the stables regularly, seven farms reported infrequent cleaning. On 30 of the study farms no disinfection was carried out.

\section{Detection of quinolone-resistant $E$. coli in environmental samples}

From six out of 26 farrowing farms, two samples of liquid manure were taken from different compartements. From all other farms a single sample of liquid manure was taken. Table 1 shows the number of different farm types where more than one sample of each dust and pen walls was taken.

In total, 104 dust samples, 104 pen wall samples and 71 liquid manure samples were examined for the occurrence of QRE. In $45.2 \%$ of the dust samples, $51.9 \%$ of the pen wall samples and $69.1 \%$ of the liquid manure samples, QRE could be detected after incubation in enrichment broth. Table 2 shows the results of the testing for FQ-resistance differentiated by sample type and farm type. Samples from breeding farms (farrowing and mating/gestation farms) were significantly more frequently positive for QRE (106 out of 177) than samples from fattening farms (44 out of 102; $\mathrm{p}<0.01$ ). Dust samples from breedings farms were significantly more found with QRE (38 out of 77) than dust samples from fattening farms (nine out of $37 ; \mathrm{p}<0.02$ ). No differences were found for pen wall samples and liquid manure samples. Samples from farms using FQ were significantly more frequently positive for QRE (88 out of 139) than samples from farms without use of FQ (51 out of 111; $\mathrm{p}<0.01)$. On farms with FQ usage, dust samples were significantly more frequently positive for QRE (31 out of 53) than on farms without FQ usage (13 out of 40; $\mathrm{p}<0.02$ ) (Table 2).

Quinolone-resistant E. coli were significantly more found in liquid manure samples from farrowing farms with FQ usage (20 out of 24 ) than without FQ usage (2 out of $5 ; \mathrm{p}<0.05)$.

Liquid manure samples generally were significantly more often positive for QRE (49 out of 71) than the dust (47 out of 104, p < 0.005) and pen wall samples (54 out of $104, \mathrm{p}<0.05)$.

Using the semi-quantitative approach, the mean colony-forming units (CFU) of QRE per $\mathrm{g}$ dust samples were $111(0-7862$, median $=0), 40$ CFU $(0-588$, median $=0)$ / g pen wall sample and $11831 \mathrm{CFU} / 1$ liquid manure. Significant higher counts of quinolone-resistant

Table 2: Results of fluoroquinolone (FQ)-resistance testing of samples from pen walls, dust and liquid manure from mating/gestation farms, fattening farms and farrowing farms. QRE + = tested positive for quinolone resistance; QRE - = tested negative for quinolone resistance; FQ +: farms with FQ usage; FO -: farms without FQ usage; nd = no data concerning FQ usage.

\begin{tabular}{|c|c|c|c|c|c|c|c|c|c|c|c|c|c|c|c|c|}
\hline & \multicolumn{4}{|c|}{ Pen wall samples } & \multicolumn{4}{|c|}{ Dust samples } & \multicolumn{4}{|c|}{ Liquid manure samples } & \multicolumn{4}{|c|}{ All sample types } \\
\hline & total & $\mathrm{FO}+$ & FQ- & nd & total & $\mathrm{FQ}+$ & FQ- & nd & total & $\mathrm{FQ}+$ & FQ- & nd & total & $\mathrm{FQ}+$ & FQ- & nd \\
\hline \multicolumn{17}{|l|}{ Farm type } \\
\hline $\begin{array}{l}\text { Mating/ } \\
\text { gestation farms }\end{array}$ & 12 & 5 & 6 & 1 & 12 & 5 & 6 & 1 & 12 & 5 & 6 & 1 & 36 & 15 & 18 & 3 \\
\hline QRE pos & 6 & 2 & 3 & 1 & 5 & 3 & 2 & 0 & 6 & 2 & 4 & 0 & 17 & 7 & 9 & 1 \\
\hline QRE neg & 6 & 3 & 3 & 0 & 7 & 2 & 4 & 1 & 6 & 3 & 2 & 1 & 19 & 8 & 9 & 2 \\
\hline Fattening & 37 & 6 & 26 & 5 & 37 & 6 & 26 & 5 & 28 & 4 & 20 & 4 & 102 & 16 & 72 & 14 \\
\hline QRE pos & 17 & 4 & 11 & 2 & 9 & 3 & 5 & 1 & 18 & 4 & 13 & 1 & 44 & 11 & 29 & 4 \\
\hline QRE neg & 20 & 2 & 15 & 3 & 28 & 3 & 21 & 4 & 10 & 0 & 7 & 3 & 58 & 5 & 43 & 10 \\
\hline Farrowing & 55 & 42 & 8 & 5 & 55 & 42 & 8 & 5 & 31 & 24 & 5 & 3 & 141 & 108 & 21 & 13 \\
\hline QRE pos & 31 & 25 & 5 & 1 & 33 & 25 & 6 & 2 & 25 & 20 & 2 & 3 & 89 & 70 & 13 & 6 \\
\hline QRE neg & 24 & 17 & 3 & 4 & 22 & 17 & 2 & 3 & 6 & 3 & 3 & 0 & 52 & 37 & 8 & 7 \\
\hline All farmtypes & 104 & 53 & 40 & 11 & 104 & 53 & 40 & 11 & 71 & 33 & 31 & 8 & 279 & 139 & 111 & 30 \\
\hline QRE pos & 54 & 31 & 19 & 4 & 47 & 31 & 13 & 3 & 49 & 26 & 19 & 4 & 150 & 88 & 51 & 11 \\
\hline QRE neg & 50 & 22 & 21 & 7 & 57 & 22 & 27 & 8 & 22 & 6 & 12 & 4 & 129 & 50 & 60 & 19 \\
\hline
\end{tabular}




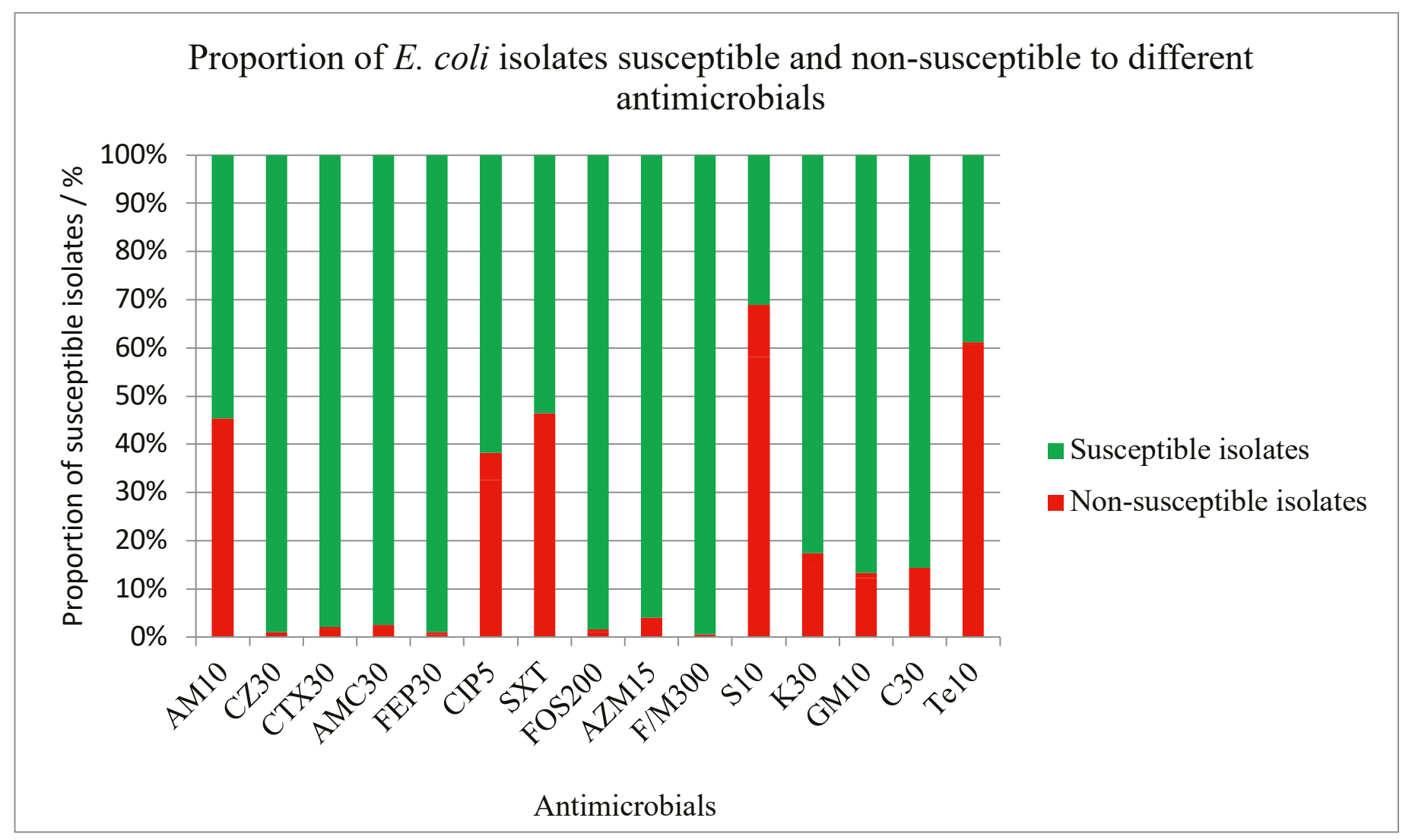

Figure 1: Resistance pofiles of QRE isolates against 15 antimicrobial agents (AM10: Ampicillin, CZ30: Cefazolin, CTX30: Cefotaxime, AMC30: Amoxicillin with Clavulanic Acid, FEP30: Cefepime, CIP5: Ciprofloxacin, SXT: Sulfamethoxazole with Trimethoprim, FOS200: Fosfomycin, AZM15: Azithromycin, F/M300: Nitrofurantoin, S10: Streptomycin, K30: Kanamycin, GM10: Gentamicin, C30: Chloramphenicol, TE10: Tetracycline). Proportion of susceptible and non-susceptible isolates.

colonies were found in liquid manure samples than in the dust or pen wall samples $(\mathrm{p}=0.001)$.

In $96.2 \%(25 / 26)$ of the farrowing to rearing farms, $79.3 \%(23 / 29)$ of the fattening farms and $80 \%(8 / 10)$ of the mating/gestation farms at least one out of samples from pen walls, dust and slurry was positive for QRE. The prevalence of QRE in at least one sample type was $97 \%(28 / 29)$ in farms with fluoroquinolone use and $85 \%$ $(23 / 27)$ in farms without fluoroquinolone use. The relative risk for the detection of QRE was 1.11 ( $95 \%$ confidence range: $0.93-1.19)$. The use of FQ was therefore not a risk factor for the detection of QRE in the environment of the farms.

\section{Sensitivity test of quinolone-resistant E. coli isolates}

From the 150 environmental samples positive for QRE, 284 isolates were cultivated and stored in pure culture (1-3 isolates per sample). Of these, 196 isolates (57 from dust, 62 from wipes and 77 from liquid manure samples) were randomly selected and tested for sensitivity to 16 antimicrobials from 10 classes (penicillins, macrolides, cephalosporins, fenicoles, tetracyclines, phosphonic acid, aminoglycosides, nitrofurantoins, quinolo- nes and sulfonamides). Figure 1 shows the percentage of non-susceptible isolates for the antimicrobials tested. Of the E. coli isolates selected with nalidixic acid, 38\% were also resistant to ciprofloxacin. The percentage of ciprofloxacin resistant isolates was almost equal for samples from farms using FQ (36\%) or not (40\%). In addition to quinolones (nalidixic acid and ciprofloxacin), the isolates were most frequently resistant to streptomycin $(69 \%)$, tetracycline $(61 \%)$, sulfamethaxole trimethoprim (46\%) and ampicillin (41\%).

In Table 3 the percentage of isolates resistant to several classes of antimicrobials is shown. Of the E. coli isolates studied, $84 \%$ were resistant to more than one antimi-

Table 3: Proportion of E. coli isolates with resistance to several antimicrobial classes.

\begin{tabular}{c|c} 
No. of antimicrobial classes & $\begin{array}{c}\text { Amount of E. coli isolates resistant to } \\
\text { one or more antimicrobial classes }\end{array}$ \\
\hline 0 & $3 \%$ \\
\hline 1 & $13 \%$ \\
\hline 2 & $22 \%$ \\
\hline 3 & $14 \%$ \\
\hline 4 & $19 \%$ \\
\hline $5+$ & $29 \%$ \\
\hline
\end{tabular}


Occurrence of quinoloneresistant Escherichia coli in environmental samples from a sow pool system in Switzerland S. von Ah et al. crobial class. Sixty-two percent were resistant to at least three and 29\% to five or more classes of active substances. $3 \%$ of the isolates showed no resistance at all.

\section{Discussion}

In the present study, QRE were found in a high proportion of study farms, regardless whether they had used FQ in the last 18 months or not. A possible reason for the higher frequency of the detection of $\mathrm{QRE}$ in liquid manure, in contrast to dust samples and pen wall samples could be the usually rare cleaning of the slurry pit and the consequently long residence time of FQ in the slurry. Chemical characteristics of antimicrobial residues in the environment vary between different active substances. ${ }^{27}$ Sarafloxacin was shown to be strongly attached to sediments and therefore less than $1 \%$ is degraded within 80 days. ${ }^{20}$ Other authors showed that enrofloxacin in the absence of solar radiation remains stable in the environment for more than 120 days. ${ }^{32}$ The long half-life of quinolones in the environment is an enduring selection advantage for quinolone-resistant bacteria. In addition, quinolone resistance in $E$. coli does not appear to have a serious effect on their fitness compared to the wild type. ${ }^{19}$ Although the use of fluroquinolones is strictly limited in Swedish chicken production, QRE isolates of a particular clone could be found in all stages of Swedish chicken production from imported grandparents. This means that QRE are able to persist in the environment for long periods independent of a selection advantage and can be spread by animal movement. ${ }^{3}$

The fact that QRE was detected less frequently in sample material from farms that did not use FQ is an indication that FQ usage may have a direct influence on the detection of QRE in the environment, in particular in dust. QRE were detected less frequently in fattening farms, where FQ usage was rare, than in breeding farms where FQ usage was more frequently observed. Another explanation for this finding could be the special experimental set-up, since the breeding sows of the sow pool were transported between the study farms and QRE may therefore have been transmitted by them. Sows housed on farms not using FQ could have been previously treated with such compounds on other farms. On the other hand, the half-life of FQ in pigs is short.2,23 While some studies show a duration of an increased excretion of antimicrobial resistant germs for three to four weeks after treatment, ${ }^{10,22,29}$ or no increased excretion of fluoroquinolone-resistant $E$. coli after treating pigs with $\mathrm{FQ}^{7}$ other authors isolated FQ resistant $E$ coli up to eight weeks after treatment with $\mathrm{FQ}^{26}$ and some data indicates that all antimicrobial therapies over the entire life are relevant, not only those carried out shortly before sampling. ${ }^{1}$ The most frequent indication for the use of antibiotics in sows in Switzerland is PDS, ${ }^{16}$ which usually occurs shortly after farrowing. Thus, an increased excretion of QRE by the sows after the transfer to the mating/ gestation farms or after transfer to the next farrowing farm has not necessarily to be assumed. Further research should address the question whether the approach to measuring antimicrobial consumption in fattening farms or in individual farms of a sow pool is effective in assessing the risk of emission of antimicrobially resistant bacteria or resistance genes or whether the selection of resistant bacteria by residues of antimicrobial agents in the environment of pig farms is more important. The coselection of quinolone resistance with the use of other antimicrobial agents may have disguised the correlation between the use of FQ and the occurrence of QRE in the environmental samples. ${ }^{24}$ Taking slurry samples was not always easy, because the slurry pit was hardly or not at all accessible. Thus, the manure in the samples in some cases was not completely homogenous or representative for the slurry pit and did not completely meet the criteria of sampling as described in literature. ${ }^{25}$ An underreporting of the prevalence of resistant $E$. coli in the slurry samples in our study is possible. Underreporting nevertheless would not contradict with our findings of QRE being widespread on the investigated pig farms.

\section{Conclusions}

QRE were widespread in the environmental samples of the farms in this study. Some associations between FQ usage and the occurrence of QRE in the environment of the farms could be observed in this study, but transport of animals and coselection may have had an influence on our results. Further investigations are needed to determine whether fluoroquinolone resistance is generally widespread in the environment of pig farms in Switzerland or the observations made only apply to the sow pool investigated in this study. Since QRE was found in nearly all farms, independent of their FQ usage, a complete freedom of QRE in the environment of pig farms may be difficult to achieve.

\section{Acknowledgments}

Special thanks are due to the producer organisation RUPROMI Swiss Schwein AG, to which the 65 study companies belonged. RUPROMI made the farmer's drug records available for examination and enabled the collection of environmental samples on the farms. 


\section{Présence d'Escherichia coli résistants à la quinolone dans des échantillons environnementaux prélevés dans un pool de truies en Suisse}

Les fluoroquinolones (FQ) subissent une métabolisation minimale chez les animaux et sont excrétées par les fèces et l'urine par l'intermédiaire desquelles elles arrivent pratiquement inchangées dans l'environnement. Dans cette étude, nous avons étudié la présence d'Escherichia coli $(E$. coli) résistants à la quinolone dans l'environnement de 65 exploitations d'un système de pool de truies en Suisse. Deux cent septante neuf échantillons de lisier, de lingettes recueillant des poussières et de parois de boxesont été collectés et l'utilisation de FQ dans les fermes a été étudiée. Sur $45 \%$ des échantillons de poussières, $52 \%$ des échantillons de parois de boxes et $69 \%$ des échantillons de lisier, des E. coli résistants à la quinolone (QRE) ont été cultivés. Des quantités significativement plus élevées de colonies résistantes à la quinolone ont été trouvées dans des échantillons de lisier par rapport aux échantillons de poussière $(\mathrm{p}<0,01)$ ou de parois de boxes $(\mathrm{p}<0,05)$. Les échantillons provenant d'élevages étaient significativement plus souvent positifs que ceux provenant d'exploitations d'engraissement $(\mathrm{p}<0,01)$. Les échantillons prélevés dans les exploitations utilisant de la FQ étaient significativement plus souvent positifs pour le QRE que les échantillons provenant d'exploitations sans utilisation de FQ ( $<<0,01)$. Sur 97\% des exploitations utilisant de la FQ et $85 \%(23 / 27)$ des exploitations sans utilisation de FQ, des QRE était présente dans au moins un échantillon (pas de différence significative). Dans l'ensemble, les QRE étaient répandus dans l'environnement des élevages porcins étudiés.

Mots clés: Résistance à la quinolone, fluoroquinolones, échantillons de lisier, profil de résistance, porcs, échantillons de poussière

\section{Presenza di Escherichia coli resisten- te ai chinoloni in campioni ambientali di un sistema di aziende di scrofe in Svizzera}

I fluorochinoloni (FQ) subiscono una metabolizzazione minima negli animali e vengono escreti attraverso le feci e le urine, dove entrano nell'ambiente quasi immutati. In questo studio abbiamo studiato la presenza di Escherichia coli (E. coli) resistente ai chinoloni nell'ambiente di un sistema di 65 aziende agricole per scrofe in Svizzera. Sono stati raccolti duecentosettantanove campioni di liquame, polvere e pareti del recinto ed è stato studiato l'uso di FQ nelle aziende agricole. Si è studiata una coltura di E. coli resistente ai chinoloni (ERC) costituita dal 45\% dei campioni di polvere, 52\% dei campioni di pareti del recinto e dal $69 \%$ dei campioni di liquame. Nei campioni di liquame sono state riscontrate colonie resistenti ai chinoloni in quantità significativamente più elevate che nei campioni di polvere $(\mathrm{p}<0,01)$ o provenienti dalle pareti del recinto $(\mathrm{p}<0,05)$. I campioni provenienti dalle aziende di allevamento sono risultati significativamente e più spesso positivi rispetto ai campioni provenienti dalle aziende di ingrasso $(\mathrm{p}<0.01)$. I campioni prelevati da allevamenti che utilizzano FQ sono significativamente e piu frequentemente positivi all'ERC rispetto ai campioni provenienti da allevamenti che non utilizzano FQ ( $\mathrm{p}<0.01$ ). Nel 97\% delle aziende che usano FQ e nell'85\% (23/27) delle aziende che non lo utilizzano, l'ERC è stata riscontrata in almeno un campione (nessuna differenza significativa). In generale si può affermare che l'ERC era diffusa nell'ambiente delle aziende di suini esaminate.

Parole chiave: Resistenza ai chinoloni, fluorochinoloni, campioni di liquame, profilo di resistenza, suini, campioni di polvere.
Occurrence of quinoloneresistant Escherichia coli in environmental samples from a sow pool system in Switzerland

S. von Ah et al.

\section{References}

1 Andersen VD, De Knegt L, Munk P, Jensen MS, Agers $\varnothing$ Y, Aarestrup FM, et al.: The association between measurements of antimicrobial use and resistance in the faeces microbiota of finisher batches. Epidemiol. Infect. 2017: 145(13): 2827-2837.

2 Bimazubute M, Cambier C, Baert K, Vanbelles S, Chiap P Albert A, Delporte J P, Gustin P: Penetration of enrofloxa cin into the nasal secretions and relationship between nasal secretions and plasma enrofloxacin concentrations after intramuscular administration in healthy pigs. J. vet. Pharmacol. Therap. 2009: 33: 183-188, doi: 10.1111/j.1365-2885.2009.01123.x
3 Börjesson S, Guillard T, Landén A, Bengtsson B, Nilsson O: Introduction of quinolone resistant Escherichia coli to Swedish broiler population by imported breeding animals. Vet. microbiol. 2016: 194: 74-78.

${ }^{4}$ Bundesamt für Gesundheit und Bundesamt für Lebensmittelsicherheit und Veterinärwesen: 2016 Swiss Antibiotic Resistance Report. https://www.blv.admin.ch/blv/de/ home/tiere/publikationen-und-forschung/statistikenberichte-tiere.html (accessed 07.08.2018)

${ }^{5}$ Bundesamt für Lebensmittelsicherheit und Veterinärwesen: $2016 \mathrm{ARCH}-$ Vet Kurzversion: Bericht über den Vertrieb von Antibiotika in der Veterinärmedizin in der Schweiz. https://www.blv.admin.ch/blv/de/home/tiere/ publikationen-und-forschung/statistiken-berichte-tiere. html (accessed 5.3.2018). 
Occurrence of quinoloneresistant Escherichia coli in environmental samples from a sow pool system in Switzerland S. von Ah et al.
${ }^{6}$ Burow E, Kässbohrer A: Risk Factors for Antimicrobial Resistance in Escherichia coli in Pigs Receiving Oral Antimicrobial Treatment: A Systematic Review. Microb. Drug Resist. 2017: 23 (2): 194-205

${ }^{7}$ Burow E, Grobbel M, Tenhagen B, Käsbohrer A: Antimicrobial resistance after fluoroquinolone treatment. Proceedings of the 7th Symposium on Antibiotic Resistance in Animals and the Environment, Braunschweig 2017: 105

${ }^{8}$ Callens B, Faes C, Maes D, Catry B, Boyen F, Francoys D, de Jong E, Haesebrouck F, Dewulf : Presence of Antimicrobil Resistance and Antimicrobial Use Are Risk Factors for Antimicrobial Resistance in their Offspring. Microb. Drug Resist. 2015: 21 (1): 50-58

${ }^{9}$ Clinical and Laboratory Standards Institute: Performance Standards for Antimicrobial Suscebtibility Testing. CLSI supplement M100S, Wayne, PA 19087 USA. 2016.

10 Delsol A, Anjum M, Woodward M, Sunderland J, Roe J: The effect of chlortetracycline treatment and its subsequent withdrawal on multiresistant Salmonella enterica serovar Typhimurium DT104 and commensal Escherichia coli in the pig. J. Appl. Microbiol. 2003: 95:1226-1234

11 Eidg. Departement des Inneren Eidg. Departement für Wirtschaft Bildung und Forschung: Strategie Antibiotikaresistenzen Schweiz StAR. https://www.blv.admin.ch/blv/ de/home/das-blv/strategien/nationale-strategie-antibiotikaresistenzen.html (accessed 5.3.2018).

12 Federation of Veterinarians in Europe. Antibiotic Resistance \& Prudent use of Antibiotics in Veterinary Medicine. http://www.fve.org/news/publications/pdf/antibioen.pdf (accessed 10.08.2018)

13 Gibbs SG, Green CF, Tarwater PM, Mota LC, Mena KD, Scarpino PV: Isolation of antibiotic-resistant bacteria from the air plume downwind of a swine confined or concentrated animal feeding operation. Environ. Health Persp. 2006: 114(7): 1032

${ }^{14}$ Hamscher G, Pawelzick HT, Sczesny S, Nau H, Hartung J: Antibiotics in dust originating from a pig-fattening farm: A new source of health hazard for farmers? Environ. Health Persp. 2003: 111(13): 1590.

15 Hamscher G, Sczesny S, Höper H, Nau H: Determination of persistent tetracycline residues in soil fertilized with liquid manure by high-performance liquid chromatography with electrospray ionization tandem mass spectrometry. Anal. Chem. 2002: 74(7): 1509-1518.

${ }^{16}$ Hartmann S.: Antibiotikaeinsatz und Tierbehandlungsindex in Schweizer Ferkelerzeugungsbetrieben. Thesis University of Zurich, 2015

17 Kruse H, Sørum H: Transfer of multiple drug resistance plasmids between bacteria of diverse origins in natural microenvironments. Appl. Environ. Microb. 1994: 60(11): 4015-4021.

18 Makita K, Goto M, Ozawa M, Kawanishi M, Koike R, Asai T, Tamura Y: Multivariable Analysis of the Association Between Antimicrobial Use and Antimicrobial Resistance in Escherichia coli Isolated from Apparently Healthy Pigs in Japan. Microb. Drug Resist. 2016: 22 (1): 28-39

19 Marcusson LL, Frimodt-Møller N, Hughes D: Interplay in the selection of fluoroquinolone resistance and bacterial fitness. PLoS pathogens 2009: 5(8).

20 Marengo JR, Kok RA, O'Brien K, Velagaleti RR, Stamm JM: Aerobic biodegradation of (14C)-Sarafloxacin hydrochloride in soil. Environ. Toxicol. Chem. 1997: 16(3): 462-471.
${ }^{21}$ Marshall BM, Levy SB: Food animals and antimicrobials: Impacts on human health. Clin. Microbial. Rev. 2011: 24(4): 718-733.

22 Mathew A, Jackson F, Saxton A: Effects of antibiotic regimens on resistance of Escherichia coli and Salmonella serovar Typhimurium in swine. J. Swine Health Prod. 2002: 10: 7-13

${ }^{23}$ Messenger K M, Papich M G, Blikslager A T: Distribution of enrofloxacin and its active metabolite, using an in vivo ultrafiltration sampling technique after the injection of enrofloxacin to pigs. J. vet. Pharmacol. Therap. 2001: 35: 452-459. doi: 10.1111/j.1365-2885.2011.01338.x.

24 Nakamura S: Mechanisms of Quinolone resistance. J. Infect. and Chemother. 1997: 3(3): 128-138.

25 Ort C, Lawrence MG, Rieckermann J, Joss A: Sampling for Pharmaceuticals and Personal Care Products (PPCPs) and Illicit Drugs in Wastewater Systems: Are Your Conclusions Valid? A Critical Review. Environ. Sci. and Technol. 2010: 44: 6024-6035

26 Römer A, Scherz G, Reupke S, Meißner J, Wallmann J Kietzmann M, Kaspar H: Effects of intramuscularly administered enrofloxacin on the susceptibility of commensal intestinal Escherichia coli in pigs (sus scrofa domestica) Vet. Res. 2017: 13:378 doi 10.1186/s12917-017-1260-8

27 Sarmah AK, Meyer MT, Boxall AB: A global perspective on the use, sales, exposure pathways, occurrence, fate and effects of veterinary antibiotics (VAs) in the environment. Chemosphere 2006: 65(5): 725-759.

28 Sukul P, Lamshöft M, Kusari S, Zühlke S, Spiteller M: Metabolism and excretion kinetics of $14 \mathrm{C}$-labeled and non-labeled difloxacin in pigs after oral administration, and antimicrobial activity of manure containing difloxacin and its metabolites. Environ. Res. 2009: 109(3): 225-231.

29 Wagner B, Straw B, Fedroka-Cray P, Dargatz D: Effect of Antimicrobial Dosage Regimen on Salmonella and Escherichia coli Isolates from Feeder Swine. Appl. Environ. Microb. 2008: 74 (6): 1731-1739 doi:10.1128/AEM.01132-07

${ }^{30}$ Winckler C, Grafe A: Use of veterinary drugs in intensive animal production. J. Soil sediment 2001: 1(2): 66.

31 World Health Organization: Tackling antibiotic resistance from a food safety perspective in Europe. World Health Organization, DK-2100 Copenhagen. 2011

32 Wu Y-b, Wang Z-s, Liao X-d, Chen Z: Study on the excretion of enrofloxacin in chicken and its degradation in chicken feces. Acta Vet. et Zootec. Sin. 2005: 36(10): 1069.

\section{Corresponding Author}

Dr. med. vet. Dolf Kümmerlen

Winterthurerstrasse 260

8057 Zurich

Tel.: +414463582 23

E-Mail: dkuemmerlen@vetclinics.uzh.ch 